\title{
Expansion of Health Networks as a Building Block of a Functioning Health Landscape
}

\section{S. Wahl (Stefan Wahl), A. Czirfusz (Attila Czirfusz)}

SEUC PhD program in Health Management and Public Health, Pharmacist, DE. Original Article

\section{E-mail address:}

vitalwelt-apotheke@t-online.de

\section{Reprint address:}

Stefan Wahl

SEUC PhD program in Health Management and Public Health, Pharmacist

Friedrichstr. 4/2

74545 Michelfeld, FR

Germany

Source: Clinical Social Work and Health Intervention

Volume: 12

Issue: 3

Pages: $24-29$

Cited references: 20

\section{Reviewers:}

Mageswaari Rajoo

Kuala Lumpur, KL

Victor Okoth

Nairobi, KE

\section{Keywords:}

Health Network. Health System. German. Patient Satisfaction. Insurance.

\section{Publisher:}

International Society of Applied Preventive Medicine i-gap

CSWHI 2021; 12(3): 24 - 29; DOI: 10.22359/cswhi_12_3_04 (C) Clinical Social Work and Health Intervention

\section{Abstract:}

\begin{abstract}
A health network is made up of institutions and organizations, resources, and people whose main purpose is to promote and improve health. The health care system in Germany is self-administering and is managed by multiple institutions and stakeholders which entails different organizations involved in the running of the health care as well as the structure of the health care system. The health care system is composed of three main areas: 1) outpatient care services, 2) inpatient care, 3) rehabilitation institutions. Some of the organizations and institutions that are mandated to run the health system include associations and representatives of different professions and service providers, regulatory bodies, health insurance companies, the Federal Ministry of Health, self-help groups, and patient-centered organizations. The German health care system is made up of four main principles: 1) compulsory insurance, 2) the principle of solidarity, 3) financing through insurance premiums, 4) self-
\end{abstract}


governance. The goal of health care networks is to improve the overall performance of the health care systems concerning: 1) economic efficiency, 2) quality of health care services, 3) medical innovation, 4) as well as patient satisfaction.

\section{Introduction}

A health network is made up of institutions and organizations, resources, and people whose main purpose is to promote and improve health. These involve efforts to influence the determinants of health and direct health enhancement activities. The health system is mandated to deliver preventive, curative, promotive as well as rehabilitative interventions through a combined effort of the health care networks. ${ }^{1}$ To perform its mandate, the health system also needs adequate staffing, finances, transport, and communication as well as the overall instructions and directions to effective functioning.

An effective health care system involves the following pillars in the health networks: 1) Delivery of health services, 2) enhancement of health workforce, 3) information systems in health, 4) improving access to essential medicines and vaccines, 5) leadership, 6) governance. These six factors are essential in the expansion and strengthening of health care systems in multiple ways. ${ }^{2}$

Service delivery is the immediate outcome of the investments made into the health system which include the workforce and supplies to the hospital financing. An increase in the inputs to the health system leads to improved access and quality of service delivery which forms the key role of the health care system. ${ }^{3}$
The effectiveness of a country's health care system depends directly on the skills, motivation, and competence of the people who are responsible to deliver health care services. The presence of a qualified and experienced workforce translates to improved outcomes in the management of patients and running of the facilities as well. Doctors, dentists, pharmacists, nurses, management, and other support staff form a very significant health network that aims to improve patient outcomes. ${ }^{4}$

The availability of reliable health information systems is the foundation of effective decision making on every health system. Information communication technology is used to improve health care processes as well as the creation of new medical innovations which purpose to address key issues in the health care system such as prevention of clinical and clerical errors, enhancing diagnosis techniques, and improvement in the management of new infectious diseases. ${ }^{5}$

For a health system to function well, there is a need for equitable access to medicine, vaccines, and technologies that guarantee safety and quality outcomes for the patients. Therefore, formulation of national policies and guidelines that regulate these practices is essential to the health system. ${ }^{6}$ In addition to that, the purchase, storage, and supply of relevant materials in a system that

\footnotetext{
${ }^{1}$ Klaus Koch et al., The German Health Care System In International Comparison, Deutsches Aerzteblatt Online, 2011, doi:10.3238/arztebl.2011.0255.

${ }^{2}$ Oliver Razum and M. Luisa Vázquez, Strengthening Public Health In Germany: Overcoming The Nazi Legacy And Bismarck’S Aftermaths, International Journal Of Public Health 62, no. 9 (2017): 959-960, doi:10.1007/s00038-017-1038-6.

${ }^{3}$ Aiqing Zhang and Xiaodong Lin, Towards Secure And Privacy-Preserving Data Sharing In E-Health Systems Via Consortium Blockchain, Journal Of Medical Systems 42, no. 8 (2018), doi:10.1007/s10916-018-0995-5.

${ }^{4}$ Arthur Gatouillat et al., Internet Of Medical Things: A Review Of Recent Contributions Dealing With Cyber-Physical Systems In Medicine, IEEE Internet Of Things Journal 5, no. 5 (2018): 3810-3822, doi:10.1109/jiot.2018.2849014.

${ }^{5}$ Mauro Serapioni, Crise Econômica E Desigualdades Nos Sistemas De Saúde Dos Países Do Sul Da Europa, Cadernos De Saúde Pública 33, no. 9 (2017), doi:10.1590/0102-311x00170116.

${ }^{6}$ Jeffrey V Lazarus et al., Novel Health Systems Service Design Checklist To Improve Healthcare Access For Marginalised, Underserved Communities In Europe, BMJ Open 10, no. 4 (2020): e035621, doi:10.1136/bmjopen-2019-035621.
} 
minimizes leakage and mixing with other waste are considered the top priority.

Financing of the health system is critical to maintain and enhance patient welfare. Without the necessary funding, there will be minimal or no promotion of health or prevention of diseases. Health financing entails mobilization and accumulation of funds to cater to the health needs of the population both at individual levels and national levels. The role of financing, therefore, is to make funds available to ensure people have access to public health as well as personal health care services. ${ }^{7}$

\section{Advantages for the patients and participants}

The goal of health care networks is to improve the overall performance of the health care systems concerning economic efficiency, quality of health care services, medical innovation, as well as patient satisfaction. Nearly a third of all physicians in practice in Germany are working in various health care networks. These networks bring together general practitioners and medical specialists in cooperation with other partners such as nursing homes, hospitals and patients led organizations, to improve the quality of medical care as well as patient satisfaction by increasing the integration and communication between the doctors and other health care workers. ${ }^{8}$

The various health networks provide access to a lot of opportunities for patients and health care workers to communicate, interact with each other and collaborate effectively to improve the quality of health care services and improve he- alth. ${ }^{9}$ These networks also help health care providers to complete their day-to-day tasks such as monitoring patient's health, checking blood pressure, and offering patients advice in various capacities. In addition to that, there is an opportunity for a multidisciplinary approach to inpatient management for both Medical and surgical procedures that entail high levels of expertise and experience. ${ }^{10}$

\section{Health networks present in German}

The health care system in Germany is self-administering and is managed by multiple institutions and stakeholders which entails different organizations involved in the running of the health and the structure of the health care system. ${ }^{11}$

The health care system is composed of three main areas: 1) outpatient care services, 2) inpatient care, 3) rehabilitation institutions. Some of the institutions that are mandated to run the health system include associations and representatives of different professions and service providers, regulatory bodies, health insurance companies, the Federal Ministry of Health, self-help groups, and patient-centered organizations. The German health care system is made up of four main principle networks, 1) compulsory insurance, 2) the principle of solidarity, 3) financing through insurance premiums, 4) self-governance. $^{12}$

The principle of compulsory insurance states that every citizen must have statutory health insurance as long as their overall gross salaries are below the set limit. However, people who earn more than the set limit can decide to have a pri-

\footnotetext{
${ }^{7}$ Timon Forster \& Alexander E Kentikelenis, Austerity And Health In Europe: Disentangling The Causal Links, European Journal Of Public Health 29, no. 5 (2019): 808-809, doi:10.1093/eurpub/cky249.

${ }^{8}$ Porter, Michael E., \& Clemens Guth. Redefining German health care: moving to a value-based system. Springer Science \& Business Media, 2012

${ }^{9}$ J.M. Badia et al., Impact Of Surgical Site Infection On Healthcare Costs And Patient Outcomes: A Systematic Review In Six European Countries, Journal Of Hospital Infection 96, no. 1 (2017): 1-15, doi:10.1016/j.jhin.2017.03.004.

${ }^{10}$ Bernd Blobel \& Peter Pharow, A Model Driven Approach For The German Health Telematics Architectural Framework And Security Infrastructure, International Journal Of Medical Informatics 76, no. 2-3 (2007): 169-175, doi:10.1016/j.ijmedinf.2006.05.044.

${ }^{11}$ Management Articles, Journals, Events, Directory I Healthmanagement.Org, Healthmanagement.Org, Last modified 2021, https://healthmanagement.org/c/it/issuearticle/facts-figures-the-german-healthcare-system.

${ }^{12}$ System, Health. Health Care In Germany: The German Health Care System. Ncbi.Nlm.Nih.Gov, Last modified 2021. https://www.ncbi.nlm.nih.gov/books/NBK298834/.
} 
vate insurance cover. ${ }^{13}$ The principle of financing via insurance premiums states that health care is funded by the insurance premiums paid by the insured employees and well as their employers. The principle of solidarity states that all citizens who are covered by the statutory insurance have equal rights to access health care services as well as continued payment of salaries and wages when they get ill regardless of the amount of income or premium level of the insurance. ${ }^{14}$

In self-governance, whereas the state establishes the protocols for health care in the country, organization and funding of individual health services are the roles of self-governing organizations within the health system. ${ }^{15}$ Members of these organizations are made up of doctors, dentists, insured people, and various hospitals.

The structure and function of the health care system in Germany is managed by the Federal Ministry of Health whose task is to develop laws and coming up with guidelines for self-governing events within the health system. The Federal Joint Committee is the top governing body that makes decisions concerning matters of statutory health insurance. It is made up of members who represent doctors, psychotherapists, hospitals, insurers, and patients. The committee determines the health services that will be covered by the insurance company as well the form that will be taken by the insurance coverage. ${ }^{16}$

Some of the significant Medical services providers as well as institutions and associations that form important health networks in German include:
- The medical insurers. Statutory health insurance companies are needed to offer health insurance and make sure that the insured gets the needed medical care.

- Doctors and non-medical psychotherapists in German who bill their services to statutory insurers belong to the association of physicians under statutory insurance while dentists are under the statutory insurance for dentists. ${ }^{17}$

- The hospital federation of Germany. This federation represents both Central as well as regional associations of different bodies that run the health care facilities such as cities, religious organizations, and private sponsors. ${ }^{18}$

- The public health service. This body is mandated to protect the German citizens from the risks of getting sick. Health departments help in the regulation of hygiene in communal settings, protecting people from getting infections and promoting good and healthy habits. They also offer counseling services to the general population for example for people with various psychosocial problems.

- The pharmacy associations. Pharmaceutical companies are responsible for the distribution and supply of medications as well as offering information and guidelines about the medications.

- Patient-based associations and self-help groups. Different people join to form help groups and organizations that offer moral support and encouragement to patients in various capacities. They also advocate for the interests and rights of patients concerning health care policies in the country.

13 "Germany I Commonwealth Fund, Commonwealthfund.Org, Last modified 2021, https://www.commonwealthfund.org/international-health-policy-center/countries/germany.

${ }^{14}$ News, Euro.Who.Int, Last modified 2021, https://www.euro.who.int/en/countries/germany/news/news/ news?root_node_selection=73561.

${ }^{15}$ Daniele Mipatrini et al., Vaccinations In Migrants And Refugees: A Challenge For European Health Systems. A Systematic Review Of Current Scientific Evidence, Pathogens And Global Health 111, no. 2 (2017): 59-68, doi:10.1080/20477724.2017.1281374.

${ }^{16} \mathrm{~J}$ Köppen et al., Measuring Efficiency Of The German Health Care System From The Population Perspective, European Journal Of Public Health 30, no. 5 (2020), doi:10.1093/eurpub/ckaa165.930.

${ }^{17}$ Ehealth Network - Public Health - European Commission, Public Health - European Commission, Last modified 2021, https://ec.europa.eu/health/ehealth/policy/network_en.

${ }^{18}$ Reinhard Busse et al., Statutory Health Insurance In Germany: A Health System Shaped By 135 Years Of Solidarity, Self-Governance, And Competition, The Lancet 390, no. 10097 (2017): 882-897, doi:10.1016/s0140-6736(17)31280-1. 


\section{Introduction}

\section{Outpatient care}

In the German health care system, outpatient care is offered by doctors, dentists, and psychotherapists who are self-employed as well as other professionals in the health care system in their private practices. General practitioners, as well as medical interns and pediatrics, are considered to be family doctors in Germany, and part of their work is to refer the patients to the right specialist for advanced treatment. ${ }^{19}$

\section{Inpatient care}

Almost all hospitals in Germany treat their patients regardless of their insurance status, whether statutory or private insurance. Additional fees are however charged when the patient has been admitted, to cover meals and accommodation in the hospital. Hospitals also provide in-patient medical rehabilitation on top of usual inpatient treatment. Rehabilitation facilities offer interventions that help patients to regain their independence and improve their wellness after recovering from a serious illness or surgical procedure. The interventions include a psychological evaluation, physiotherapy as well as learning how to use medical appliances. ${ }^{20}$

\section{References}

1. GERMANY I COMMONWEALTH FUND (2021) Commonwealthfund.Org, Last modified 2021. https://www.commonwealthfund. org/international-health-policy-center/countries/germany.

2. MANAGEMENT ARTICLES (2021) Journals, Events, Directory I Healthmanagement. Org. Healthmanagement.Org, Last modified 2021. https://healthmanagement.org/c/it/issuearticle/facts-figures-the-german-healthcaresystem.

3. NEWS. EURO (2021) Who. Int, Last modified 2021. https://www.euro.who.int/en/ countries/germany/news/news/news?root_no de_selection $=73561$.
4. ACHSTETTER K, KOPEN J, BLUMEL M, BUSSE R (2020) Are Persons With A Limited Health Literacy Less Satisfied With The German Health Care System? European Journal Of Public Health 30, no. 5 (2020). doi:10.1093/eurpub/ckaa166.049.

5. BADIA J M, CASEY A L, PETROSILLO, HUDSON P M, MITCHELL S A, CROSBY C (2017) Impact Of Surgical Site Infection On Healthcare Costs And Patient Outcomes: A Systematic Review In Six European Countries. Journal Of Hospital Infection 96, no. 1 (2017): 1-15. doi:10.1016/j.jhin.2017.03.004.

6. BLOBEL B, PHAROW P (2007) A Model Driven Approach For The German Health Telematics Architectural Framework And Security Infrastructure. International Journal Of Medical Informatics 76, no. 2-3 (2007): 169175. doi:10.1016/j.ijmedinf.2006.05.044.

7. BUSSE R, BLUMEL M, KNIEPS F, BARNIGHAUSEN T (2017) Statutory Health Insurance In Germany: A Health System Shaped By 135 Years Of Solidarity, Self-Governance, And Competition. The Lancet 390, no. 10097 (2017): 882-897. doi:10.1016/s01406736 (17)31280-1.

8. DIETRICH C (2012) Editorial Zum Beitrag Challenges For The German Health Care System. Zeitschrift Für Gastroenterologie 50, no. 06 (2012): 555-556. doi:10.1055/s-00321312772.

9. EHEALTH NETWORK - PUBLIC HEALTH - EUROPEAN COMMISSION. PUBLIC HEALTH - EUROPEAN COMMISSION (2021) Last modified 2021. https://ec.europa.

eu/health/ehealth/policy/network_en.

10. FORSTER T, KENTIKELENIS A E (2019) Austerity And Health In Europe: Disentangling The Causal Links. European Journal Of Public Health 29, no. 5 (2019): 808-809. doi:10.1093/eurpub/cky249.

11. GATOUILLAT A, BADR Y, MASSOT B, SEJDIC E (2018) Internet Of Medical Things: A Review Of Recent Contributions

\footnotetext{
${ }^{19} \mathrm{~K}$ Achstetter et al., Are Persons With A Limited Health Literacy Less Satisfied With The German Health Care System?, European Journal Of Public Health 30, no. 5 (2020), doi:10.1093/eurpub/ckaa166.049.

${ }^{20}$ C. Dietrich, Editorial Zum Beitrag Challenges For The German Health Care System, Zeitschrift Für Gastroenterologie 50, no. 06 (2012): 555-556, doi:10.1055/s-0032-1312772.
} 
Dealing With Cyber-Physical Systems In Medicine. IEEE Internet Of Things Journal 5, no. 5 (2018): 3810-3822. doi:10.1109/jiot. 2018. 2849014.

12. KOCH K, MIKSCH A, SCHURMANN CH, JOOS S, SAWICKI P T (2011) The German Health Care System In International Comparison. Deutsches Aerzteblatt Online, 2011. doi:10.3238/arztebl.2011.0255.\&

13. KOPPEN J, ACHSTETTER K, BLUMEL M, BUSSE R (2020) Measuring Efficiency Of The German Health Care System From The Population Perspective. European Journal Of Public Health 30, no. 5 (2020). doi:10.1093/ eurpub/ckaa165.930.

14. LAZARUS J V, BAKER L, CASCIO M, ONYANGO D, SCHATZ E, SMITH A C, SPINNEWIJN F (2020) Novel Health Systems Service Design Checklist To Improve Healthcare Access For Marginalised, Underserved Communities In Europe. BMJ Open 10, no. 4 (2020): e035621. doi:10.1136/ bmjopen-2019-035621.

15. MIPATRINI D, STEFANELLI P, SEVERONI S, REZZA G (2017) Vaccinations In Migrants And Refugees: A Challenge For European Health Systems. A Systematic Review Of Current Scientific Evidence. Pathogens And Global Health 111, no. 2 (2017): 59-68. doi:10.1080/20477724.2017.1281374.

16. MOLD JAMES (2017) Goal-Directed Health Care: Redefining Health And Health Care In The Era Of Value-Based Care. Cureus, 2017. doi:10.7759/cureus.1043.

17. RAZUM O, VAZQUEZ M L (2017) Strengthening Public Health In Germany: Overcoming The Nazi Legacy And Bismarck'S Aftermaths. International Journal Of Public Health 62, no. 9 (2017): 959-960. doi:10.1007/s00038-017-1038-6.

18. SERAPIONI M (2017) Economic Crisis and Inequalities in Health Systems in Southern European Countries. Public Health Notebooks 33, no. 9 (2017). doi:10.1590/ 0102-311x00170116.

19. SYSTEM, HEALTH (2021) "Health Care In Germany: The German Health Care System". Ncbi.Nlm.Nih.Gov, Last modified 2021. https://www.ncbi.nlm.nih.gov/books/NBK29 8834/.

20. ZHANG AIQING, XIAODONG LIN (2018)
Towards Secure And Privacy-Preserving Data Sharing In E- Health Systems Via Consortium Blockchain. Journal Of Medical Systems 42, no. 8 (2018). doi:10.1007/s10916018-0995-5. 